\title{
Racismo e Experiência do Lugar em Estudantes Negras e Negros'
}

\author{
Racism and Experience of Place in Black Students
}

Diogo Marçal Cirqueira *

\begin{abstract}
Resumo:
O objetivo desse artigo é analisar a trajetória sócio-espacial de estudantes negras e negros nos/pelos lugares de educação formal. Tendo como influência o livro de Rezende (1986), "A geografia do aluno trabalhador", busca-se produzir uma "geografia da(o) estudante negra(o)". Para dimensionar a experiência desses estudantes em sua amplitude temporal-espacial, nos utilizamos da noção de trajetória sócio-espacial. Por conta do racismo existente nos lugares de educação formal, a experiência de estudantes negras(os) é marcada por frustrações e desencantamentos, o que expressa, em alguns casos, uma relação topofóbica com essas espacialidades. Isso é apresentado nas narrativas dos estudantes onde encontramos termos para significar suas trajetórias educacionais como "terror", "medo", "sofrimento" e "desânimo". Tais fatos confirmam a assertiva de alguns geógrafos quando afirmam que identidades raciais de sujeitos definem padrões diferenciados de experiências do espaço. A atuação do racismo, assim, conduz estudantes negras(os) a experiências marcadas pela violência, negação e fixação em lugares simbólicos, pois, conformam trajetórias marcadas por experiências de humilhação; desqualificação e demérito; desmotivação e desestímulo; e inculcação de um senso de deslocamento, como se estivessem "fora-de-lugar". Isso demonstra os limites dos discursos universalistas difundidos nesses lugares e nos impele a enfrentar e buscar mecanismos mais efetivos para desconstruir o racismo.
\end{abstract}

\section{Abstract:}

The aim of this paper is to analyze the socio-spatial trajectory of black students in/by institutional education places. Having as influence the book "A geografia do aluno trabalhador" [The geography of student worker] by Resende (1986), I pretend to produce a "geography of the black student". In order to make this, the socio-spatial trajectory notion is important because it allows us to scale the time-spatial black students' experience through the places. The black students' experiences are marked by disappointments and setbacks because of the racism in the institutional education places, which conjures a topofobic relationship with these spatialities. This is presented in the students' narratives where we find the use of terms as "terror", "fear", "suffering" and "discouragement" to signify their school trajectories. These facts confirm the ideas developed by some geographers who claim that the racial identity of individuals and groups define different patterns of experience in space. The racism in society leading the black students to experiences marked by violence, denial and fixation on physical and symbolic places. They have trajectories marked by humiliating experiences; disqualification and demerit; demotivation and discouragement; and inculcation of a sense of displacement and being "out-of-place." It demonstrates the limits of the universalist discourses widespread in the places of education and impels us to confront and seek more effective mechanisms to deconstruct racism.
* Dr. em Geografia pela UFF e Professor de Geografia no Instituto de Educação de Angra dos Reis (IEAR-UFF)

Palavras-chave:

Educação,

Racismo,

Trajetória sócio-espacial, Lugar

Key-Words:

Education,

Racism,

Socio-spatial trajectory,

Place. 


\section{INTRODUÇÃO}

$\mathrm{O}^{-1}$ objetivo principal desse artigo é discutir a trajetória sócio-espacial ${ }^{2}$ de estudantes negras e negros nos/pelos espaços de educação formal. Primeiramente, deve-se ressaltar que este trabalho é fruto de uma pesquisa mais abrangente sobre estudantes negras e negros da Universidade Federal de Goiás (UFG) realizada em 2008. A investigação foi feita no âmbito da Geografia e, à luz da significativa ampliação e avanço das discussões a respeito das relações étnico-raciais com um viés geográfico (cf. CIRQUEIRA, CORREA, 2014), busca debater esse tema tendo como foco a experiência nos lugares ${ }^{3}$.

Deve-se, nesse sentido, mencionar a influência e inspiração encontrada no livro "A geografia do aluno trabalhador" (RESENDE, 1986). Para além da crítica abstrata aos conteúdos, técnicas e metodologias do ensino, esta obra apresenta outros caminhos da pesquisa sobre educação em Geografia ao demonstrar o quanto a história de vida, ou melhor, a "geografia da vida" dos sujeitos, compõe e condiciona seus processos de ensino-aprendizagem. Focando em indivíduos de "carne e osso", Resende denota que a experiência de vida e a consciência geográfica prévia é modular na prática do convívio escolar dos sujeitos inseridos no processo educativo. Esse horizonte aberto pela autora, foi fundamental para se pensar a própria "geografia $\mathrm{da}(\mathrm{o})$ estudante negra(o)".

As discussões realizadas aqui também estão conectadas e fundamentadas numa série de pesquisas qualitativas sobre as relações étnico-raciais na educação (CAVALLEIRO, 2005, 2000; MUNANGA, 2005; GOMES, 1995, 2005; BRASIL, 2004; TEIXEIRA, 2003), além de pesquisas estatísticas sobre o mesmo assunto (IPEA 1999; PNUD 2005; CASTRO e ABRAMOVAY, 2006; CASTRO e RIBEIRO, 2008). Estas investigações evidenciam desigualdades profundas entre estudantes de diferentes pertencimentos raciais na educação formal. Em especial, são emblemáticos os dados divulgados pela UNESCO no trabalho "Relações Raciais na Escola: reprodução de desigualdades em nome da igualdade" (CASTRO e ABRAMOVAY, 2006) sobre a atuação do racismo na educação básica. Como esta investigação evidencia a ação do racismo no espaço escolar, proporciona às/aos estudantes negras(os) proficiências médias inferiores a de estudantes brancas(os). A pesquisa, realizada junto a lecionandos que continham índices socioeconômicos similares e situações educacionais idênticas, revelou que o desempenho de ne- gras (os) é mais baixo do que de brancas(os). A conclusão desta pesquisa é que a "discriminação racial" tem sido um fator que, desestimulante, gera baixo rendimento escolar, aumento e possibilidade de repetência, além de atuar como redutor na frequência às salas de aulas por parte desses estudantes.

É importante destacar, ainda segundo a pesquisa, que esses problemas das diferenças médias de desempenho entre os dois grupos pesquisados se tornam mais agudos à medida que as(os) alunas(os) avançam as séries do sistema educacional. Esse processo tem reflexos diretos no acesso ao ensino superior, pois a atuação do racismo, conjugado muitas das vezes à formação escolar precária condicionada por circunstâncias socioeconômicas baixas, forja em estudantes negras(os) um sentimento de inferioridade e baixa autoestima. Isso, ou dificulta o acesso direto à universidade ou influencia na forma como estes ingressam nessa instituição - levando em conta que buscam nas universidades, sobretudo, os cursos menos concorridos e de menor status social (cf. QUEIROZ, 2004; TEIXEIRA, 2003). Não é por acaso que Queiroz (2004, p.144), ao realizar pesquisa sobre o corpo estudantil em universidades brasileiras, chega à conclusão que "as Universidades Federais são um espaço de predomínio de estudantes brancos" .

A despeito de uma volumosa produção sobre as exclusões que o racismo gera na educação formal, a maioria destas investigações (qualitativas e quantitativas) se restringiram à educação básica, com algumas exceções (TEIXEIRA, 2003). Apesar de terem surgido pesquisas quantitativas sobre a composição do corpo estudantil universitário no país - pelas quais sabemos da presença ínfima de estudantes negras(os) nas universidades (PNUD, 2005; PAIXÃO et al., 2010), temos poucas pesquisas qualitativas tratando desse nível de ensino. Por isso, pretende-se preencher as lacunas referentes aos dados quantitativos sobre essa questão, buscando-se entender como se dá a trajetória vivenciada por estudantes negras(os) nos vários lugares de educação formal até o seu ingresso e permanência na universidade. É fundamental e necessária uma análise qualitativa das trajetórias sócio-espaciais das(os) estudantes negras(os) que conseguiram chegar à universidade, tendo em vista compreender quais as dificuldades e obstáculos enfrentados por estas(es) até chegarem a esse nível de ensino.

Outra falta detectada nesses trabalhos é a ausência de uma mirada sobre a dimensão espacial desse problema. Ainda que se considere a raça ou o racismo como um condicionador histórico das relações e da produção/re- 
produção de desigualdades na educação formal no Brasil, perde-se de vista as diferenciações expressas e expressadas no/pelo espaço. Santos (2012), em sua discussão sobre a "espacialidade das relações raciais", evidencia como os processos de auto-identificação e alter-identificação são condicionados pela posição dos sujeitos. De alguma forma, o autor nos deixa crer que há contextos espaciais de interpelação racial; há distinções escalares nesse processo que podem envolver tanto lugares em uma cidade, como apresenta o próprio autor, quanto em contextos regionais no Brasil (TELLES, 2004). Isso expressa de alguma forma que ser negra(o) ou branca(o) não possui sentidos e efeitos idênticos em todos os lugares ou regiões no território nacional brasileiro. $\mathrm{Na}$ educação ou no espaço escolar isso não é diferente, a espacialidade força a uma multiplicidade de contextos de experiência (e interpelação) acerca dos quais devemos estar atentos.

Dessa forma, buscando articular as discussões geográficas sobre lugar e as teorias das relações étnico-raciais, e tendo como horizonte uma bibliografia que frisa a atuação do racismo na vida escolar de negras(os), as questões que nos guiarão nas discussões subsequentes são: Quais as dificuldades enfrentadas por estudantes negras(os) nos lugares de educação formal? A atuação do racismo influencia na maneira como as/os estudantes experienciam os lugares de educação formal? Quais são as estratégias conformadas por estes sujeitos para contornar os obstáculos criados pelo racismo?

Para elaborar respostas a esse conjunto de questões, ao empregar métodos qualitativos, serão apresentadas narrativas de estudantes negras(os), enfatizando suas reflexões sobre racismo, escolarização e experiência espacial. Assim, este artigo, se utilizará de perspectivas relacionadas à geografia humanística ${ }^{5}$, nos moldes de Tuan (1982) e Buttimer (1982). Esse horizonte teórico funcionará como um aporte à compreensão da "condição humana" e do "mundo humano", bem como seu processo de desumanização, além de auxiliar na análise dos sentimentos e ideias a respeito do espaço e do lugar, muitas vezes, topofóbicos e negativos. Acredita-se que essa perspectiva possibilite tratar adequadamente da violência do racismo que atinge subjetivamente a população negra (SOUZA, 1983), principalmente em uma realidade "hiperracializada", como a brasileira, que impede muitos de perceber esse problema (VARGAS, 2005). Ademais, a geografia humanística pode dar mais sentido e (des)humanidade aos números frios das estatísticas, tal qual, demonstrar como a herança histórica da escravidão, do patriarcado e do racismo (CARNEIRO, 2005) ainda se encontram presentes e operando em nosso cotidiano, interferindo, por exemplo, na maneira como pessoas negras experienciam o lugar.

$\mathrm{O}$ artigo estruruta-se da seguinte forma: primeiramente, serão apresentadas as bases teóricas que envolvem as narrativas de vida e a teorização geográfica; em seguida, as questões relativas a influência do racismo nas trajetórias sócio-espaciais; as trajetórias sócio-espaciais de estudantes negras(os) no ensino básico; posteriormente no ensino superior; e, por fim, as considerações finais.

\section{NARRATIVAS DE VIDA E GEOGRAFIA}

Nos últimos anos emergiram uma série de pesquisas que buscam tratar de biografias com lentes geográficas. Esse conjunto de trabalhos vem chamar a atenção para a importância da dimensão espacial nesse tipo de investigação. Ao se enfatizar a importância extremada destinada à temporalidade, estes autores e autoras apontam, criticamente, para a ausência de miradas junto ao espaço em produções e análises biográficas (REGARD, 2002; WOLF-MEYER, HECKMAN, 2002). Há também trabalhos que apontam para a necessidade de uma reflexão autobiográfica no próprio processo de produção do conhecimento na Geografia. Como destaca Moss (2001), por exemplo, metodologias ligadas à reflexão autobiográfica complexificam - para um pesquisador - o lugar, o contexto e as relações de poder que envolvem a produção do discurso geográfico.

Propriamente, na esteira de Hägerstrand (1970), propõem-se nessas abordagens aportes teóricos assentados na junção de espaço e tempo. Como indica Karjalainen (2003), a articulação entre estas dimensões em uma biografia nos permitem realizar análises mais complexas e mais profundas do fenômeno biográfico, isso porque, de acordo com o autor, o "aqui e agora" é um tipo de densidade a partir de onde a dispersão de tempo e espaço acontecem concomitantemente, ou seja, espaço e tempo são dinâmicos, agentes e interagem entre si para conformar uma vida. Desse modo, no tipo de análise que se apresenta, deve-se agregar ao "espaço vivido" o "tempo vivido" e vice-versa.

A despeito desse conjunto de trabalhos adotarem o termo "geobiografia" (geobiography) para se pensar o curso de uma vida a partir dos tempos-espaços vividos, opta-se, aqui, por utilizar a terminologia trajetória sócio-espacial. Acredita-se que esta nomenclatura expressa uma ideia de movimento, por conseguinte, de algo não-acabado e que imprime interações (aproximações e distanciamentos com outras trajetórias) (BOURDIEU, 1996; MASSEY, 2008; CIR- 
QUEIRA, 2010, 2008). Pensando dessa forma, em linhas gerais, trajetória sócio-espacial envolve a historicidade e a espacialidade de vida(s); um conjunto de experiências contidas no espaço-tempo que possuem uma conformação não linear ou contínua. A importância da espacialidade se faz na medida em que as experiências humanas são topocentradas e, muitas das vezes, os lugares demarcam momentos e limites dessas trajetórias no tempo, firmando-se como referências experienciais simbólicas para sujeitos. Como bem aponta Tuan (1983, p. 94), "sagrado e enraizado, o lugar permanece no íntimo das pessoas ainda que metamorfoseado ou devastado [em sua materialidade]". Desse modo, para se compreender as trajetórias sócio-espaciais, deve-se construir os estados sucessivos do campo no qual elas se desenrolam; os vários lugares e experiências pelas quais os indivíduos perpassam, unindo um ator social a outros cujas vivências se desenvolvem no mesmo campo e no mesmo conjunto de possibilidades (BOURDIEU, 1996; MASSEY, 2008).

Por essa acepção, deve-se ressaltar que nas trajetórias sócio-espacias - assim como em uma perspectiva geobiográfica - há uma tríade que trabalha simultanea e sistematicamente: lugar, memória e ser/estar (KARJALAINEN, 2003). Em outros termos, entre tempo-espaço existe a memória, e, muitas das vezes, esta se constitui a partir de narrativas e discursos múltiplos, os quais dão sentido e concretude à vida no mundo, a trajetória.

Frente à mediação do discurso, há que se ressaltar as dificuldades que envolvem analisar uma trajetória sócio-espacial. Como menciona Kofes (2001), uma série de problemáticas cercam o processo de narrar o outro, pois, toda narrativa é uma versão parcial, posicionada e carrega um pouco do narrador. Em outras palavras, não existe uma narrativa universal que consiga expressar a totalidade da trajetória de uma pessoa, ela é sempre marcada por lacunas e perspectivas.

Por conta dessa contradição, alguns autores enfatizam que as biografias e autobiografias são uma espécie de "heterotopia construída", algo que consiste em um "pacto biográfico". Heterotopia porque o autor constrói um mundo utópico, um lar ou monumento onde o ser - do narrador ou do narrado - se expressa (REGARD, 2002). E um pacto porque nas narrativas sobre si e sobre o outro há uma promessa de sinceridade do narrador, algo que se constitui, contraditoriamente, como uma ficção. O narrador não é uma pessoa que fala a verdade, mas sim, uma pessoa que diz falar a verdade (LEJEUNE,1990). Isso, de forma alguma, quer dizer que uma narrativa biográfica seja falsa ou inverídica. $\mathrm{O}$ que esses autores buscam ressaltar é o fato de que a narrativa de uma história de vida está marcada por escolhas, ditos e não-ditos, que não deixam de ter efeitos (internos e externos) na subjetividade e realidade dos que narram.
Como as discussões acima demonstram, é quase que impossível se colocar neutro na tarefa de contar a história de uma vida, uma vez que a narrativa sempre traz em si as pegadas do narrador. Da mesma forma, não existem narrativas de vida totais e fora de um contexto. Estas são definidas por questões e enredos prévias. Experiência dos sujeitos da pesquisa aqui são multiplas e envolvem uma série de fatores, contudo, nosso foco é compreender como suas negritudes ressoam em suas experiências em espaços educacionais. Isso possui uma relação direta com os efeitos do racismo nesses lugares.

\section{TRAJETÓRIAS SÓCIO-ESPACIAIS E O RA- CISMO}

Pesquisas sobre as relações étnico-raciais evidenciam que as problemáticas concernentes a esse campo se inscrevem de forma marcante no espaço. Como afirmam alguns autores, existe uma "dimensão espacial das relações étnico-raciais" (RATTS, 2003, 2004) ou "uma espacialidade das relações raciais" (SANTOS, 2011, 2012). Devemos ressaltar, no entanto, que isso não ocorre somente na maneira como indivíduos se distribuem e se organizam no espaço - principalmente na configuração de "segregação racial" como demonstraram Silva (2006) e Neto e Riani (2007), mas, também, na forma como indivíduos brancos(as) e negros(as) experienciam e vivenciam o espaço, tanto no plano individual quanto no coletivo.

Primeiramente, ao pensar as relações étnico-raciais no Brasil, não se pode perder de vista que a formação social brasileira é marcada pela escravização de africanos (MOORE, 2007). Além disso, uma representação negativa do sujeito negro foi amplificada e consolidada nos imaginários e corpos dos brasileiros por teorias "científicas" racialistas (MUNANGA, $2004,1998)$. Tendo em vista esses fatores implicados à nação, como indica Ratts (2004), a racialidade perfaz múltiplas escalas - algo que vai do ambiente familiar até as desigualdades no território nacional e, de maneira marcante, define o senso de espaço de pessoas negras e de outros pertencimentos raciais.

A experiência do racismo e essa memória da escravidão estão fundidas, principalmente, na corporeidade dos sujeitos negros. O corpo, nesse caso, ao tempo que é um efetivo "produtor do espaço" e o artífice das experiências do indivíduo no lugar (CARLOS, 1996; CRESSWELL, 2004), conforma hierarquias raciais (NOGUEIRA, 1985; SANTOS, 2000, 2002[2000],1996/1997). O racismo influencia na constituição dos lugares, uma vez que é aí onde o corpo negro é percebido/percebe, é significado/significa e é colocado em encontro/confronto. Em linhas gerais, é no lugar onde con- 
vergem as experiências e vivências determinadas pelo racismo ou relações racializadas. Daí a importância de se lançar luz sobre os lugares das trajetórias sócio-espaciais, seja em sua dimensão topofilica (TUAN, 1981, 1983) ou topofóbica (RELPH,1978, 1976) ${ }^{6}$, já que assim, pode-se compreender até que ponto os privilégios e desvantagens que a raça cria definem experiências de sujeitos no lugar.

Essa leitura encontra eco no trabalho "Memória em branco e preto: olhares sobre São Paulo", de Bernardo (1998). Nesta obra a autora discute as representações de mulheres e homens negras(os) e brancas(os) acerca da cidade de São Paulo. Como fica explicito, não somente os olhares são diferentes entre estes grupos, como também suas formas de experienciar os lugares em São Paulo. Pessoas negras (homens e mulheres), em muitos casos condicionados pelo racismo e o terror racial, narram uma dimensão degrada material e simbólica dessa cidade, algo completamente diferente das narrativas de pessoas brancas. O interessante é que essa distinção na narrativa dos dois grupos, ocorre sobre lugares que ambos experienciaram e, em alguns casos, compartilharam.

De alguma forma, Bernardo apresenta de maneira concreta, o que a geógrafa Mcktrick (2006) vem chamando atenção: uma longa história de expropriação e violência conectadas a processos de escravização e terror racial, imperiosamente, define e informa a percepção e senso de lugar das pessoas negras (e brancas) no presente.

Como veremos a seguir, isso também tem reflexos diretos na maneira como pessoas negras experienciam os lugares de educação formal.

\section{ESCOLA, "LUGAR DE NEGRO..."?}

Antes de tudo, deve-se ressaltar que as(os) estudantes negras(os), em suas trajetórias sócio-espaciais, perpassam por uma diversidade de lugares que dão sentido e imprimem significados por meio de suas prórias experiências. Nesse sentido, ainda que restrito, o foco aqui se restringe aos lugares da educação formal, inicialmente a escola - ensino infantil, fundamental e médio - e posteriormente a Universidade, uma vez que foram citados repetidamente pelas(os) estudantes como um dos lugares onde experimentaram os reveses da diferença racial e do racismo.

Inicialmente a estudante de Pedagogia, $\mathrm{Maya}^{7}$, dá o tom dessa problemática. A mesma relata os inconvenientes que vivenciou na escola juntamente com sua irmã. Migrante de uma cidade do interior do estado do Maranhão e provinda de família pobre, a lecionanda narra as "diferenças" que encontrou na escola pública para onde se transferiu em Goiânia. Dentre elas é destacado o racismo dos colegas:
Parece que a escola [no Maranhão] funcionava no ritmo da comunidade. A gente está vivendo essa festividade agora [se referindo as festas que ocorriam na cidade] e a escola seguia isso, e isso era muito gostoso (...) Era uma relação de cumplicidade, a gente era muito cúmplice dentro da escola. A maior diferença que eu tive na escola do Maranhão pra cá, e minha irmã também teve, é que no Maranhão a gente... Assim, aluno, aluno! e aqui não, a gente chegou e era "neguinha", "pretinha" (...) Era uma coisa pejorativa, era pra te deixar pra baixo.

Doci (estudante de Nutrição), relata ter frequentado colégios particulares onde era visível a não presença de pessoas negras, isso a levava, assim como outros estudantes negros, a serem colocados frequentemente em evidência. Contudo, como a mesma narra, isso se dava de forma negativa: "eu lembro que na $7^{a}$ série foi o ano em que mais teve negros estudando comigo, eram 8 de 40 alunos. Nós nos sentávamos todos juntos, e as pessoas falavam, 'ali é a periferia da sala', as vezes até nós mesmos falávamos isso num tom de brincadeira, sabe".

A fala das estudantes evidencia como os estereótipos raciais atravessam a experiência de estudantes negras(os). Como um tipo de "imagem de controle" (COLLINS, 1999), além de criar um sentido de estranhamento, fixa um "lugar social" para esse grupo e conduz a um processo de auto-identificação defensória; negras(os) além de serem vistas(os) como as (os) diferentes, são relacionadas (os) à pobreza, à "periferia", a algo considerado negativo. Em uma espécie de fuga psicológica ou uma auto-defesa as(os) estudantes abarcam esses "pré conceitos" e se auto-identificam por meio deles.

Claudia (estudante de Medicina) talvez demonstre com maior argúcia a amplitude desse problema e as suas implicações espaciais, uma vez que apresenta a escola como um locus de reprodução de valores e experiências racialmente hierarquizadas. Ela estudou em colégios semelhantes aos da estudante citada acima, onde era ínfima a presença de negras(os) e a tensão racial, em sua leitura, era constante. A estudante chega a qualificar as escolas onde estudou como "meio hostil". Ao ser questionada a respeito desse meio ser hostil, diz:

(...) acho que o meio é hostil porque no colégio sempre tive apelidos; cabelo de bombril, cabelo disso, cabelo daquilo..., o livro didático, eu não sei como é hoje, mas antigamente era só o menininho e a menininha branquinha, sabe? Todo mundo feliz, branco... Acho que isso acaba sendo hostil num país como o Brasil. É revista, é televisão... é um modelo de beleza importado, europeia. Todo mundo acha que é o bonito e que você não se enquadra. Nas aulas de geografia sempre falavam, "nossa no Nordeste só tem gente feia”. Ah é, porque que no nordeste só tem gente feia? Porque lá só tem negro, mestiço e mulato e no sul só tem loiro do olho azul?... Isso é hostil pra mim.. 
Para além de pensar o espaço escolar como um contexto de tensões raciais, a fala de Claudia dá relevo ao que várias(os) autoras(es) vem afirmando acerca da escola, isto é, este local está repleto de práticas racistas, que vão desde as relações interpessoais até o material didático-pedagógico utilizado (CAVALLEIRO, 2000, 2005; GOMES, 2005; GOMES E SILVA, 2002; SILVA, 2003).

No bojo desse contexto de tensões raciais, podemos destacar os insultos racistas ao quais as(os) estudantes negras(os) são submetidos. O "insulto racial", como denota Guimarães (2002), se configura como uma tentativa de legitimar uma hierarquia social baseada na ideia de raça, ou um "processo ritual" que, retomando um significado socialmente construído para o corpo, visa "ensinar" aos inferiorizados a subordinação e a subserviência através da humilhação.

O relato de Milton (Estudante de Filosofia) exemplifica bem a discussão feita acima.

Na época que eu estudava no Seminário estava tendo um even-
to, tinha vários padres e seminaristas, e estava havendo uma
confraternização. Eu estava conversando com o Padre Osmar,
que era uma pessoa que tinha um certo grau de importância na
Diocese, aí me parece que o Padre Edmilson, que era o atual
reitor do seminário, não sei se ele se sentiu incomodado... Aí,
eu mais alguns amigos estávamos conversando com o padre
Osmar, e veio o padre Edmilson e falou, mais ou menos assim,
"abriram as portas da senzala", e depois ele falou assim citando
meu nome, "bom eram os tempos dos grilhões e dos troncos".
Na hora fiquei muito nervoso, mas tentei revidar da forma mais
tranquila. Ai, falei assim, "não sei como um cara, professor, teó-
logo e filosofo, tido como 'cabeça' na Diocese ainda tem esses
preconceitos tão antigos e da mais alta ignorância". Na época
rolou a maior discussão, as pessoas que estavam no local todas
se voltaram contra ele. Tiveram outros fatos também, mas eu
não gosto muito de relatar..

Em síntese, tendo em vista nosso passado histórico escravista, nada melhor para reafirmar a "subalternidade" de uma pessoa negra do que taxá-la de escravo. O interessante do caso citado, é que essa afirmação racista foi cometida por um professor, ou melhor, por um "Padre, reitor de seminário, teólogo e filosofo". Isso demonstra, como é explicitado por Cavalleiro (2005), que a maioria dos profissionais da educação não estão preparados para tratar da questão étnico-racial na educação. Estes, tendem a silenciarem-se frente ao ato racista, naturalizando-o $\left(\right.$ CAVALLEIRO, 2000) ${ }^{8}$, ou, às vezes, são os próprios agentes da atuação explicita do racismo. Isso também derruba uma série de mitos que relegam a ação racista à "pessoas ignorantes e não escolarizadas". Na medida que professores vivem em uma sociedade estruturada pelo racismo, estão propensos a reproduzir essas relações, algo que se coloca independente do grau escolaridade.

No relato seguinte isso também fica evidente, observando-se a angústia e reação da estudante diante disso:
No cursinho, foi um professor de matemática, ele chegou na frente rindo e as pessoas perguntaram o que era, e era uma piada, era uma piada racista. Eu não me lembro o conteúdo da piada, só sei que tinha um judeu, um negro, não sei mais quem. Eu não me lembro da piada. Ele contou e todo mundo achou muita graça, todo mundo riu. Eu fiquei muito impressionada. Gente, no ano de 2005... eu fiquei muito chocada. Aí, assim, eu não levantei o braço, mas eu deveria ter levantado. Eu já dei muita "rata" na minha vida! Porque eu fiquei muito sem graça, mas eu mandei um bilhete: "é uma vergonha pro nosso país um professor racista, um professor que leciona num país como o Brasil e ser racista. O que você tá ensinando para seus alunos?”. Eu fiquei completamente decepcionada e me senti extremamente ofendida, mandei esse bilhete pra ele sem assinar nem nada, deveria ter assinado. (CLAUDIA, ESTUDATE DE MEDICINA).

As mitificações criadas no bojo da escravização dos povos africanos e as construções pseudo-científicas do século XIX, pressupunham um desenvolvimento desigual entre as "raças humanas" (SANTOS, 2005). Fatores que estavam inseridos nesse ideário eram a não-humanidade e a emocionalidade exacerbada da pessoa negra, em outras palavras, a animalidade e a incapacidade intelectual. Na escola estes pressupostos permanecem vivos e se manifestam por meio das ofensas, xingamentos, apelidos, enfim, dos insultos raciais. Isso fica expresso na fala de Sofia (estudante de Letras) também, que além de ser insultada como "burra", um animal que é sinônimo de não inteligência, é impedida de se relacionar com colegas pelo fato de ser negra:

Essa fase [ensino fundamental] foi quando eu mais sofri com o preconceito mesmo. É a fase que as crianças são mais ruins. Elas falavam, "essa negra burra... ah, não sabe de nada". Como eu sempre fui boa aluna sempre os professores me defendiam... uma vez eu briguei com uma colega, eu tinha uns 12 anos, porque ela não queria que eu fosse colega do irmão dela porque eu era negra. Foi muito difícil.

Nos relatos, o corpo negro parece ser o principal alvo dos insultos raciais e da violência simbólica na escola, especialmente o cabelo. Cláudia (estudante de Medicina) nos conta os problemas referentes ao seu cabelo no colégio em que estudou:

No colégio sempre tive apelidos; "cabelo de bombril", "cabelo disso", "cabelo daquilo...", sabe? Essas hostilidades sempre acontecem, com bilhetinho, esse tipo de coisa (...) "Claudia você gostaria de almoçar na minha casa, porque no final você poderia usar seu cabelo para ajudar minha mãe a lavar as louças", anônimo. E Verbal, assim, tem aquele menino chato que você briga com ele e ele fala: "oh, cabelo de bombril", etc. .

Apesar das manifestações racistas ocorridas nas escolas estarem majoritariamente no plano do discurso, do insulto racial, não significa que o limite seja este. A violência física pautada pelo racismo também foi relatada. Como expõe Maya (Estudante de Pedagogia) acerca de sua irmã.: 
A gente sofria muito com as implicâncias dos meninos. Chegaram a cortar o cabelo dela [da irmã]. 'é bombril, é bombril!', eles ficavam gritando. Ela ficou aterrorizada. Ela não queria voltar à escola. Inclusive apanhou pra voltar pra escola. Acho que isso fez com ela perdesse completamente o ânimo de estudar.

Essa citação talvez reflita, no geral, o sentimento que a atuação do racismo na escola proporciona à(ao) estudante negra(o): “terror, medo, sofrimento, desanimo...”. Nessas circunstâncias podemos entender, ao menos em parte, porque as taxas de evasão entre estudantes negras(os) é maior do que a de estudantes brancas (os) (IPEA, 1999); e porque, também, um bom desempenho de estudantes negras (os) é menor do que de estudantes brancas(os) (CASTRO e ABRAMOVAY, 2006).

Uma estudante, resumidamente, diz o que significava o lugar escola para ela, e que de certa forma, também significa para maioria das(os) entrevistadas(os): "por conta dessas coisas que aconteciam com minha irmã, e comigo mesmo, a escola para mim era um tormento (...) Eu tinha pavor imenso de escola." (MAYA, ESTUDANTE DE PEDAGOGIA).

Diante do exposto, nota-se que os problemas do racismo experienciados na escola, marcados por piadas, apelidos, brincadeiras, risos zombeteiros, chegando incluisve à violência física, estabelecem um impacto profundo junto à(ao) estudante negra(o), como é possível observar nos relatos acima. Isso as(os) leva

\begin{abstract}
a auto-rejeição, desenvolvimento de baixa auto-estima com ausência de reconhecimento de capacidade pessoal; rejeição ao seu outro igual racialmente; timidez, pouca ou nenhuma participação em sala de aula; ausência de reconhecimento positivo de seu pertencimento racial; dificuldades no processo de aprendizagem; recusa em ir à escola e, consequentemente, evasão escolar (CAVALLEIRO, 2005, p. 12).
\end{abstract}

Apesar disso, as (os) estudantes não se colocam inertes a esse processo racista, elas(eles) estabelecem vários mecanismos de reação para se "defender", algo que possui ressonância direta na maneira como "percebem", significam e exercem interação com/nesse lugar. Um dos mecanismos de autodefesa é a "auto-invisibilização" em sala de aula: a(o) estudante busca formas de não ser percebida (o) em sala de aula.

Várias estudantes mencionaram ter esse tipo de comportamento, que é marcado estritamente pelo "medo" e pela "vergonha"; " medo de se manifestar, vergonha de ser vista (o).

a auto-rejeição, desenvolvimento de baixa auto-estima com auEu sempre ficava na última cadeira, não sei se era pra me preservar, eu mesmo criei aquela barreira... não sei. (...) Quando a professora falava pra mim ler, eu pensava que tinham que me levar para o hospital, eu começava a tremer, suar, vinha uma nuvem escura nas minhas vistas... eu não gostava. Gostava de ficar lá no fundo: "não me vejam, não estou aquil" (ZORA, ESTUDANTE DE MÚSICA).

Uma vez que os discursos que inferiorizam o negro são tidos como "naturais" e "algo normal" na escola, principalmente por não existirem outros discursos que a eles se contraponham, outro mecanismo de defesa é partir para a própria luta física. Já que não há o conhecimento de argumentos que possam desconstruir os estereótipos, a "briga" é a única solução, como demonstra o relato:

(...) Eu fui para Escola Agrícola Experimental Dom Bosco, é uma ONG italiana que atua na América Latina. Foi nessa época, dentro dessa escola, que eu passei pelos piores problemas. Entrando nos problemas raciais. Na minha época tinha dois ou três negros, no máximo, na escola, apesar de todos serem de baixa renda... Como eu não conhecia nada sobre a questão de justiça, não sabia que existiam leis para esse tipo de coisa, achava que era comum, minha reação era juntar minha turminha e partir pra briga, partir pra porrada mesmo. Desde criança eu nunca tolerei esse tipo de coisa, nem piadinha, a não ser hoje, que já sei quando as pessoas me tratam carinhosamente. (MILTON, ESTUDANTE DE FILOSOFIA)

De acordo com Souza (1983, p. 40), tido como inferior na sociedade, o(a) negro(a) precisa redobrar seus esforços, potencializar ao máximo suas capacidades, ser o melhor. Isso, continua a autora, "na realidade, na fantasia, para se afirmar, para minimizar, compensar o 'defeito', para ser aceito". Essa era uma das atitudes das(os) estudantes frente ao conflito étnico-racial na escola - ser a melhor para contrabalançar os processos de restrição e os estereótipos de inferioridade. Como salienta Kizzy (estudante de Economia):

Tem situações tão naturais que a gente nem percebe que está sendo alvo de discriminação. Às vezes você entra num lugar as pessoas te olham diferente, não sei se pelo jeito de se vestir ou pela cor da pele. Às vezes você está num grupo, alguém tem que ser escolhido, você tinha tudo para ser escolhido e não foi. Por que? Entendeu... Mas, eu tento contornar tudo disso, fazendo sempre o melhor de mim. Eu tento correr atrás do prejuízo, porque esse é um fator que infelizmente interfere na minha vida e na sociedade... Porque ser negro é diferente de ser branco. (...) Na escola, eu lembro que demorou muito até eu conseguir impor respeito em relação a isso [a discriminação racial]. Eu sempre fiz questão de me destacar e me impor, e provar para as pessoas que eu poderia ser a melhor.

Para Maya (estudante de Pedagogia) tirar boas notas era o símbolo dessa "fuga", como podemos observar:

Eu sempre tento muito me superar. No ensino fundamental era mais uma forma de fugir. Eu tinha que ser a melhor aluna porque as pessoas enchiam tanto a minha paciência que uma forma de mostrar pra eles que... bom, vocês podem me chamar de "neguinha", falar o que for, mas eu vou sempre ser a melhor da turma. Eu sempre tirava um dez, e era minha forma de me vingar. No ensino médio, não. Eu fiquei mais quieta. (MAYA, ESTUDANTE DE PEDAGOGIA). 
Ainda assim, alguns efeitos negativos se manifestavam como uma derivação colateral da afirmação constante de ser a melhor, mediante a inferiorização racializada. Por exemplo, Zora (estudante de Música), fazendo eco ao relatos acima, fala dos problemas que o "rótulo" de ser a melhor, aliado ao "medo", the proporcionaram:

Eu gostava da escola, porque eu gosto de estudar. Eu até era rotulada [como boa aluna], não sei se eu fazia isso pelo rótulo ou porque eu era negra, ou pelos dois. Eu sempre tirava notas muito boas, eu era sempre apontada na sala como a que tira nota boa. Meus pais também sempre falavam, "ela tira nota boa, é a melhor da sala", aquelas coisas de pais. Eu tive um problema com isso e estou resolvendo agora aqui na faculdade, depois desse tempo todo. Porque é difícil sair do rótulo. $\mathrm{Na}$ época em que eu terminei a $8^{a}$ série tinha prova pro CEFET, e eu queria fazer Escola Técnica. Aí, eu queria fazer Eletrotécnica, mas eu não fui porque eu tinha medo de não passar e decepcionar meus pais. E eu fiquei com isso até hoje. $\mathrm{O}$ vestibular também eu retardei por muito tempo com medo de não passar, devido esse rótulo... "Como, uma menina nota dez não passar?!?". O rótulo é horrível.

Por fim, serão de destacadas duas falas. A primeira diz respeito a uma situação em que uma estudante negra é surpreendida com uma piada racista:

Eu fiz cursinho preparatório para o vestibular (...) um colega de Anápolis, não sei se tem alguma coisa a ver, mas muita gente pode ser loira e não ter preconceito, ele era branco do olho azul. Eu tava conversando com um colega e ele veio rindo falando, "gente eu tenho uma piada pra falar pra vocês", e contou uma piada racista. Era assim, "qual é a diferença entre o negro e a pilha"... Gente, eu fiquei calada, não acreditei, como ele veio contar isso pra mim, uma negra. Deve ser porque algumas pessoas negras devem achar isso muito normal pra ele ter vindo falar isso pra mim. Ai eu fiquei parada e meu colega ficou muito sem graça, porque ele era muito amigo meu. Ai, ele continuou: "é que a pilha tem um lado negativo e outro positivo, e o negro só tem o lado negativo". Eu lembro que, ninguém tinha vindo pra mim pra contar uma piada racista antes, eu fiquei muito chocada, juro por deus. Eu fiquei sem reação, eu devia ter falado alguma coisa. Eu não falei nada, eu fiquei muito assustada. (CLAUDIA, ESTUDANTE DE MEDICINA)

Nesse relato é nítida a - aparente - "normalidade" com que o ato racista ocorreu, demonstrando como se dá a atuação do racismo na escola: violento e ao mesmo tempo natural. Ainda assim, como também se pode observar, o ato não é algo dissimulado; talvez não seja perceptível para aquele que aciona tais preconceitos, um garoto "branco dos olhos azuis, contudo para aquele que é afligido com o racismo, são atingidos com extrema violência. Com isso o que se pretende refletir é que: o que parece ser natural e invisível ao olhos de alguns, pode e, muitas vezes, é uma experiência extremamente traumática e aterrorizante para outras(os).

O segundo relato conjuga os vários relatos citados acima e levanta os problemas pelos quais negras e negros passam no ensino formal básico, isto é, adversidades eco- nômicas, a atuação do racismo e a própria negação de sua capacidade intelectual. Isso implica imaginar que a(o) estudante que passa por esse nível de ensino é um verdadeira(o) "sobrevivente".

Nas escolas quando você não tem uma condição financeira muito boa, as pessoas te excluem, não te deixam entrar nos grupinhos etc. E as pessoas que são negras e não tem dinheiro é mais complicado. Você sobrevive porque tem que sobreviver, você tem que suportar... Ser negro e ser pobre é muito complicado, e ter dignidade mais ainda. Porque as pessoas te olham com outro olhar... Primeiro, se você é negro as pessoas te olham e falam logo, "você é empregada doméstica, você é pedreiro...", as pessoas tem dificuldade em aceitar que você é negro, é inteligente, que você tem dignidade e que você consegue as coisas, sem fazer alguma coisa errada. (SOFIA, ESTUDANTE DE LETRAS)

\section{A UNIVERSIDADE, "UMA FACA DE DOIS GUMES...”}

Sem dúvida, a atuação do racismo no ensino básico, aliado a outros fatores, influencia na trajetória de estudantes negras(os) a ponto de interferir em projetos e escolhas na vida (TEIXEIRA, 2003; QUEIROZ, 2004). A opção do curso, a opção da universidade em que participará do processo seletivo, a idade em que se submeterá à seleção e, consequentemente, quando entrará na universidade, é um dilema para as(os) estudantes negras(os). Isso, ainda que sejam problemas para estudantes de vários segmentos sociais, no tocante aos estudantes negros, recaem de forma incisiva (TEIXERA, 2003; QUEIROZ, 2004).

A maioria dos sujeitos dessa pesquisa refletem as assertivas colocadas acima. Muitos tiveram que começar a trabalhar muito cedo e aliar o estudo em escolas públicas precárias com o trabalho. Além disso, tiveram que conviver com o racismo, o que influenciou em suas escolhas e decisões, como podemos observar nos seguintes relatos:

A dificuldade que eu tive para entrar na faculdade foi que eu tinha que estudar e trabalhar muito. Aí eu trabalhava a tarde e estudava de manhã. Trabalhava numa academia de natação. Cheguei a prestar duas vezes o vestibular e não fiz cursinho. Você tinha outra opção de curso?

Sim, psicologia. Mas eu sabia que nunca ia passar. Como esse curso era muito difícil e concorrido, resolvi fazer Geografia mesmo, que é menos concorrido e eu gostava também. (PEDRO PAULO, ESTUDANTE DE GEOGRAFIA)

... Eu era rotulada [como boa aluna], não sei se eu fazia isso pelo rótulo ou porque eu era negra, ou pelos dois. Eu sempre tirava notas muito boas, eu era sempre apontada na sala como "a que tira nota boa" (...)

Por que você decidiu fazer música?

Eu sempre gostei de música. A primeira música que eu ouvi eu senti uma emoção tão grande... Assim, até hoje eu lembro a primeira música que eu ouvi, eu tinha uns três, quatro anos, foi a música dos Beatles, Hey Jude. Eu falei, “nossa...”. Até 
hoje a música me emociona, sabe? $\mathrm{E}$ eu retardei esse processo de medo de não passar mesmo... pelo rótulo. (ZORA, ESTUDANTE DE MÚSICA)

Pode-se considerar esses relatos como "normais" entre estudantes de baixa renda, no entanto, mesmo que isso não se coloque de forma nítida, à primeira vista, a violência do racismo - interseccionada com outros fatores - proporciona às(aos) estudantes negras(os) uma situação psicológica desvantajosa frente às(aos) estudantes brancas(os): o "medo", a desmotivação, a autoestima baixa etc., construídos devido a uma trajetória influenciada pelo racismo, são os principais aspectos disso. Como observa Bourdieu (1996, p. 188),

o nível de aspiração dos indivíduos se determina, em grande parte, em referência às probabilidades (intuitivamente estimadas através dos sucessos ou das derrotas anteriores) de atingir o alvo visado. 'Aquele que vence', escreve Lewin, 'situa seu próprio alvo' um pouco mais (mas não muito) acima de seu último êxito. Assim ele eleva regularmente seu nível de aspiração (aquele que malogra, por outro lado, pode ter duas reações diferentes: ele pode situar seu alvo muito baixo, frequentemente aquém de seu êxito passado (...) ou então, ele situa seu alvo acima de suas possibilidades.

Como é possível notar nos relatos de Pedro Paulo e Zora e, refletindo sobre o que aponta Bourdieu, os sujeitos da pesquisa em grande parte fizeram escolhas que recaíram sobre cursos da área de humanas, carreiras menos valorizadas no mercado de trabalho e menos concorridas no exame vestibular. Essas atitudes foram consideradas por elas(eles) como "realistas" diante das possibilidades a que se colocavam. Isso demonstra um nível mais baixo de "aspiração", o que, acreditamos, esteja vinculado às experiências marcadas pela discriminação, como também, às "limitações" impostas por uma origem nas classes sociais desfavorecidas.

Podemos perceber a desmotivação imposta às(aos) estudantes negras(os) devido ideias racistas, como a de "incapacidade intelectual", um estigma que as(os) persegue antes e depois da entrada na Universidade:

\footnotetext{
... Fiz da primeira a quarta série numa escolinha de Santa Rosa. Nessa época também foi a primeira vez que ouvi falar sobre universidade pública, e que lá só passava filho de rico... Cheguei até a ouvir de um dono da fazendo que meu pai trabalhava que universidade pública não era pra preto. Essas pilantragens que você escuta quando é Criança. (MILTON, ESTUDANTE DE FILOSOFIA)
}

Quando eu entrei pelo vestibular não existia essa questão de cotas aqui, mas, quando eu passei na UFG, eu ouvi muita gente dizer que só passei porque foi por cotas. Eu perguntei, "por que, você acha que eu não tenho capacidade para passar na universidade?". E quando a gente faz esse tipo de pergunta para as pessoas elas não conseguem responder, porque elas não conseguem assumir o preconceito. Só que falam através de piadas, de situacões, mas quando a gente enfrenta elas, elas ficam sem argumentos... Eu escutei isso de um médico. Ele falou pensando que eu não estava ouvindo, aí eu perguntei, "por que você acha que eu passei só por causa das cotas, se quando eu passei não existia, não estava aprovado", ai ele falou, "é brincadeira", dando desculpa. (SOFIA, ESTUANTE DE LETRAS)

Os relatos acima, além de refletirem o preconceito, que estereotipa a pessoa negra como menos capaz intelectualmente, ainda exprimem a dimensão espacial que atravessa material e subjetivamente a trajetória dos estudantes. Há um ideário que delimita os espaços destinados a brancas(os) e negras(os) (cf.: RATTS, 2004; MCKITTRICK, 2006; SANTOS, 2012), e a Universidade pública parece não ser um "lugar de negro". Além do mais, a segunda fala evidencia uma das características perversas do racismo brasileiro: apesar de violento, se esconde atrás “da brincadeira”, o que não permite a defesa daquele que sofre a ação racista.

Essa imposição de uma "não capacidade intelectual" e o consequente não espelhamento para com a Universidade, leva as(os) estudantes negras(os) acharem que este "é um espaço inalcançável." (Celie, estudante de Artes) ou, como mencionou uma das entrevistadas: "pra mim era o Olímpo, um lugar para os deuses. Muito longe de mim.” (ZORA, ESTUDANTE DE MÚSICA).

Outro fato que está vinculado a estes, é o local 'Universidade" não figurar no imaginário e nas perspectivas para o "futuro" das(os)estudantes negras(os), anteriormente ao acesso. Sofia (estudante de Letras) demonstra isso quando questionada sobre sua "visão" referente à universidade antes de nela ingressar: "Eu não tinha ideia nenhuma. Eu entrei na Universidade sem ter uma visão do que era universidade."

Já Maya (estudante de Pedagogia), provinda de família pobre, que não pôde lhe proporcionar uma base para o planejamento futuro dos seus estudos, teve como principal incentivador o pai. Como a estudante relata, ao findar o ensino médio não possuía qualquer ideia do que era a universidade, principalmente a pública, e seu objetivo principal era se inserir no mercado de trabalho - como a maioria das/os estudantes negras/os e pobres.

\footnotetext{
Eu não tinha nem uma ideia sobre a universidade. Aconteceu foi o seguinte: eu ia terminar o segundo grau e ia trabalhar, como todo mundo na periferia pensa, mas meu pai dizia: "quem não estuda, não tem futuro!", e ele falou pra mim: “o que você quer fazer?" e eu respondi: "eu vou trabalhar", e ele, "não, você vai entrar na universidade". Isso foi um choque pra mim, porque meu pai é pedreiro, minha mãe empregada doméstica. Assim, entrar na universidade foi atitude dele: "Maya vai entrar na universidade!". E muita gente ficou: “não, a menina tem 18 anos, tá boa pra trabalhar", e ele, "não, ela vai estudar!”. (MAYA, ESTUDANTE DE PEDAGOGIA).
}

Outro aspecto que podemos destacar na trajetória dessa estudante diz respeito à escolha do curso na Universidade. Mesmo com referências que influenciaram em sua escolha, esbarrou não somente nos problemas econômicos, mas também no "estranhamento" junto às pessoas de um 
dos cursos ao qual optou.

$\mathrm{Na}$ época foram os dois cursos que me chamaram atenção: pedagogia e psicologia. Pedagogia sempre teve uma história comigo, minha mãe queria ser professora, além dessa história da minha infância com meus professores. Já Psicologia, eu vim conhecer o curso antes. Porque ninguém tinha noção de nada lá em casa. Eu visitei o curso na [Universidade] Católica, mas pense numa pessoa que se sentiu 'um peixe fora d'água'. Não sei, parece que eu não me identifiquei com as pessoas, com a faculdade. Eu gostei muito do curso, mas não consegui me achar (...) Pelo que eu vi as pessoas que estudavam no curso tinham uma condição financeira bem elevada... meu pai iria conseguir pagar o curso, disso eu tinha certeza, mas e aí? Como eu vô fazer com os livros? Como vô fazer com as coisas? E esse pessoal? Eu estava visitando com uma amiga minha e eles ficavam olhando assim, e eu... "que que eu to fazendo aqui?". Eu não me achei no curso, na estrutura do prédio. Aqui na faculdade educação eu olhei assim, as pessoas com as carinhas mais amistosas, pessoas que pareciam que tinham uma condição, sei lá, igual a minha. (MAYA, ESTUDANTE DE PEDAGOGIA).

Com a entrada na UFG, uma das questões citadas pelas(os) estudantes negras(os), foi o estranhamento referente às pessoas ao próprio lugar. Os entrevistados se manifestaram incomodados, principalmente, com a pouca quantidade de pessoas negras na UFG e realizaram reflexões sobre os efeitos disso em suas vidas acadêmicas.:

A universidade, apesar de ser um lugar de troca de conhecimento e de diferença, é um lugar muito diferente do meu bairro e de onde vive a maior parte da minha vida. É outro mundo. É segregado, né? Os negros, os não-brancos são segregados, e não estão aqui dentro... Isso fica muito evidente aqui. (PEDRO PAULO, ESTUDANTE DE GEOGRAFIA)

Quando eu entrei, me senti num lugar estranho. Era um lugar muito grande pra mim. Eu me sentia assim, "o que eu to fazendo aqui? quem sou eu?". O comportamento das pessoas, a distância mesmo, física, né (risos). Mas assim, é um lugar dos sonhos e depois que você ta lá dentro você fica meio perdida. Eu me sentia perdida, eu tinha medo de ir aqui e ali, porque eu não sabia se podia entrar em certos lugares, entrar na sala, entrar na biblioteca. (ZORA, ESTUDANTE DE MÚSICA)

\section{E continua a estudante,}

As vezes eu me sinto sozinha, né? Teve uma palestra que eu participei na universidade, eu olhei assim, você só vê você de negra. Na sala de aula só tem brancos. Assim, aí a gente se sente sozinha.

Você acha que isso influencia na sua vida acadêmica?

Sim. Nessas escolhas de ficar na frente, eles não vão colocar uma pessoa diferente das outras, vão deixar essa pessoa mais atrás, por último. Que nem a mulher falou né? "deixe seu currículo e aguarde que eu vou te procurar", mas isso não acontece . (ZORA, ESTUDANTE DE MÚSICA) ${ }^{9}$

Referente à universidade, encontramos perspectivas diferenciadas entre algumas entrevistadas. Fatores como a familia e a escola que frequentaram no ensino fundamental e médio tiveram uma grande influência. Cláudia (Estudante de
Medicina), provinda de uma familia de profissionais da medicina, teve toda uma estrutura para ingressar neste mesmo curso; não somente a influência de referências pessoais na famillia, como também incentivo econômico para permanecer por um longo tempo se preparando para o vestibular.

Eu me lembro que isso [o vestibular] me aterrorizava no terceiro ano, porque eu queria fazer medicina, mas eu tinha medo. Eu sabia que não ia passar. E aí prestei pra veterinária, porque eu tinha esperança de chegar lá e gostar. Aí, fiz uma semana, olhei e pensei "não tem jeito!". Fiz três anos de cursinho e passei pra medicina. (...) Eu não sei se tem influência do meio, acho que com certeza deve ter, pois meu pai é médico, minha mãe é médica. Sei como é a rotina, cresci ouvindo isso, cresci vendo isso... Não sei se teve influência pra mim, mas acho que a gente não ta livre, nossas escolhas tem influência de alguma coisa, querendo ou não. Mas assim, foi vontade mesmo. Eu sabia como era o ritmo, eu achava interessante, eu achava legal, achava apaixonante. O que eu queria fazer de minha vida, sabe?

No entanto, quando Cláudia é questionada sobre sua estada na UFG e a questão étnico-racial, a mesma alega não ter vivenciado problemas "explícitos" de racismo na universidade, de outra forma, percebe a falta de estudantes negros em sua faculdade e reitera:

$\mathrm{Eu}$, como uma estudante de medicina, acho que sou uma minoria muito grande [se referindo a ínfima ou inexistente presença de negras/os no curso de medicina]. Porque na minha sala não tem nenhum negro, só eu de negra. Da faculdade tem os estudantes africanos, como estudantes de convênio... eu só conheço três negros que posso considerar negros em toda a faculdade de medicina.

Continuando a refletir sobre o fato de ser uma pessoa negra em um lugar majoritariamente composto por brancas - "a exceção" - Cláudia se utiliza do exemplo do pai, que é negro e professor da Faculdade de Medicina da UFG para ponderar sobre essa questão:

Meu pai é professor da [Faculdade de] Medicina, faz muito tempo, desde da década 70 (...) Meu pai tem aquela imagem de "bom brasileiro": que saiu da pobreza, que lutou muito, que é negro, chegou lá com força de vontade e hoje é médico. As pessoas adoram meu pai, acham ele um exemplo. Então, essa é a imagem do meu pai, e ele é negro e é muito calado. Eu não sei o que ele viveu no passado, o que ele sofreu de preconceito. Lógico que ele sofreu alguma coisa, eu já perguntei uma vez, mas ele não fala nada. Lógico que ele sofreu alguma coisa, acho que ele não quer falar. Mas ele é querido por todos. Eu converso isso com a minha mãe, né? Será que isso é verdadeiro ou será que eles aumentam o carinho porque meu pai é negro e tá lá também e isso dá um status diferente para as pessoas. Sei lá, será se as pessoas se aproximam pra diminuir a culpa, pra falar que tem um amigo negro, não sei, sabe? (CLAUDIA, ESTUDANTE DE MEDICINA).

Milton (estudante de Filosofia) também fala sobre o fato de ser negro na UFG e sobre as relações, que, como o mesmo coloca, se dão de forma "camuflada", mas ao mes- 
mo tempo atuantes no que se refere ao racismo:

Quem é negro sabe. Sabe que em determinados espaços da universidade que você vai as pessoas te olham diferente... é muito difícil falar, porque você percebe olhares diferentes, sempre que você está em um local em que vai ser distribuído funções.. Você vai na reitoria, por exemplo... eu fui na reitoria com quatro amigos meus, brancos, e percebi um tratamento diferenciado entre nós. Cumprimentaram eles e não me cumprimentaram... algumas amigas minhas negras também notaram isso, não sei se você notou? (...) Aqui na universidade, na UFG, as pessoas conseguem camuflar muito bem algumas coisas...

Várias(os) das (os) entrevistadas(os) falaram das experiências envolvendo a questão étnico-racial na universidade, no entanto, aqui será destacada, dentre essas, uma estudante. A mesma ingressou no ano de 2003 no curso de Pedagogia, ano em que o debate acerca das políticas de Ação Afirmativa entrou em evidência, devido à implementação de cotas em algumas universidades brasileiras. Além disso, a entrevistada participou de um projeto de Ação Afirmativa na UFG para estudantes negras(os), denominado "Projeto Passagem do Meio"10. Como a mesma menciona, ela era sempre fustigada em sala de aula no que diz respeito às discussões sobre "relações raciais", por ela ser negra e também por participar de um projeto de Ação Afirmativa. Isso a deixava extremamente constrangida, o que ocasionou brigas com os/as colegas de turma e a levou ao seu isolamento em sala de aula:

(...) eu briguei com minha turma no primeiro ano. Eles falavam que um aluno não deveria ganhar bolsa só por que é negro. Argumentos que são ultrapassados... (...) Nesse último ano, eu falei: "quer saber, eu vou pro noturno". Eu não conheço ninguém, eu chego e fico no canto, entro e saio, sem problema. Não gosto muito de... A gente já tem uma violência com nosso espaço tão grande... acho que assim, a vida já deu tanto tapa que brigar pra que, eu vou ficar quieta no meu canto. (MAYA, ESTUDANTE DE PEDAGOGIA).

A esse respeito, a estudante conclui dizendo de sua decepção referente aos vários momentos conflitantes em que foi colocada à prova e, ainda, sobre a desilusão com a universidade:

E desde pequena que eu bato de frente: eu bati de frente estudando pra mostrar que eu era a melhor da sala, pra tirar notas boas; eu bati de frente quando as pessoas me ignoravam; eu bati de frente no superior quando eu argumentava, quando alguns alunos provocavam terrivelmente e eu dava resposta, mas eu ficava triste, ficava decepcionada (...) Justamente por causa do trabalho, da correria, da briga que tive logo no primeiro ano com meus colegas de classe; eu ficava meio que isolada. Então, a universidade está sendo uma coisa meio chata pra mim, eu só estou cumprindo uma questão burocrática. (...) Eu mesmo falo pra os meus colegas, os poucos que sobraram, que a Faculdade de Educação pra mim é de passagem, eu to passando por aqui porque eu tenho que ter um certificado de conclusão do ensino superior. Isso pra mim perdeu aquele valor).
Dando continuidade a seu relato, Maya, juntamente com Doci, estudantes que estavam em fase final nos cursos, fazem uma reflexão em sua trajetória na Universidade e explicitam:

Acho que correspondeu [no que se refere a troca de conhecimentos], mas eu não consegui viver a universidade como deveria ter vivido. $\mathrm{E}$ acho que um dos fatores que influenciou nisso foi o fato de eu ser negra. (MAYA, ESTUDANTE DE PEDAGOGIA)

Eu to tão louca pra sair dela [da Universidade]... Minha mãe fala que eu vou sentir saudade da faculdade, pra mim não vai fazer diferença nenhuma. Aqui é muita competição, uma pessoa derrubando a outra. (DOCI, ESTUDANTE DE NUTRIÇÃO)

De alguma maneira, como se nota, a Universidade cria um contexto de desmotivação para alguns estudantes. De fato, há um sentimento de deslocamento e desidentificação com esse espaço, algo que tem a ver com o conjunto de relações sociais e simbólicas que vigoram aí, mas que também está relacionado com as diferenças raciais ali presente. Em outros termos, estudantes negras e negros não encontram modelos com os quais possam se identificar na universidade. Nesse sentido, como processos pedagógicos possuem uma associação com (re)conhecimento, a quebra desse processo pelo estranhamento, gera nada menos que o desestímulo e desmotivação.

Por fim, destaca-se o relato de um estudante ao ser indagado sobre o significado do lugar "Universidade" para ele. Eis a resposta:

Todo mundo que entrou na universidade entra com uma concepção e sai com outra. Antes de eu entrar achava que aqui era um lugar perfeito, um espaço totalmente diferente do mundo de lá. Depois, atualmente,... não vou negar que a Universidade tem seu lado bom, onde você pode ter uma boa vivência com uma diversidade de pessoas, mas ela também não deixa de ser um monstro; é competitivo demais, de falsidade demais, onde você vai as pessoas querem puxar seu tapete... $\mathrm{Na}$ universidade você encontra uma injustiça camuflada.

É minha visão de universidade, é uma faca de dois gumes. Ao mesmo tempo que ela é boa, é fantástica e te dá um número grande de conhecimento, vem o outro gume da faca, por traz do conhecimento tem a pessoa querendo enfiar uma ideia na sua cabeça a qualquer custo, estão querendo te fazer pensar certo tipo de coisa, estão querendo que você abandone suas ideologias, estão querendo deturpar seu pensamento, estão querendo que você deixe de lado suas crenças... Pensando no caso de quem é negro, estão querendo te europeizar a qualquer custo, querendo te transformar num europeu... Se brincar te fazer pensar que você tem cabelos escorridos e olhos azuis. (MILTON, ESTUDANTE DE FILOSOFIA)

\section{CONSIDERAÇÕES FINAIS}

Essas análises se unem a um conjunto de produções no campo da Geografia que evidencia como a identidade 
racial de sujeitos e grupos define padrões diferenciados de experiência do espaço. No que se refere à população negra, reminiscências de um passado escravista e a atuação do racismo, conduzem à experiências marcadas pela negação $\mathrm{e}$ a fixação em lugares simbólicos e físicos. A maneira como estudantes negras e negros vivenciam os lugares de educação formal, expressa essa problemática, pois, como visto nos relatos, esses lugares são marcados por uma série de tensões que conduzem a processos de estranhamento junto às/aos estudantes. Factualmente, seria necessário fazer esse tipo de pesquisa com estudantes brancos/as para que se pudesse realizar comparações e compreender as distinções nos processos de produção de subjetividades racializadas nos lugares de educação formal, contudo, de qualquer forma, os relatos evidenciam os limites de discursos universalistas nesses espaços. Parece haver aí uma "mais-valia psicológica" (GONZALEZ,1979) que leva as/os estudantes à construção de um auto reconhecimento distorcido acerca de si, algo que prejudica suas formações educacionais e contribui para expulsá-las física e simbolicamente desses lugares.

Nesse sentido, outro aspecto que se deve chamar a atenção é, mesmo que as/os estudantes possuam trajetórias sócio-espaciais distintas entre si, definidos por vários marcadores de diferenciação, como sexualidade, gênero, classe social, local de moradia etc., a experiência do racismo, de certa forma, conecta suas trajetórias. As narrativas que tratam das tensões que envolvem a diferença racial nos lugares de educação formal são muito semelhantes. Isso nos deixa entender que há padrões na maneira como o racismo se manifesta nesses lugares, algo que envolve a humilhação - muitas das vezes por meio de piadas; a desqualificação e o demérito; a desmotivação e o desestímulo; e a inculcação de um senso de deslocamento e de se estar "fora-de-lugar".

Diante disso, como enfatizam alguns autores, deve-se tanto romper com o silêncio acerca da atuação do racismo no espaço escolar (CAVALLEIRO, 2000), quanto romper com projetos e ideários inocentes de cunho universalista (SANTOS, 2010) - como por exemplo, a afirmação acrítica da existência de uma "democracia racial" nos espaços escolares. Deve-se de fato tensionar e enfrentar o racismo nos lugares de educação formal. Isso envolve a conformação de mecanismos contundentes para superá-lo. Só assim conseguiremos construir lugares (de toda ordem) diversos, plurais e saudáveis para todos os pertencimentos étnicos e raciais.

Portanto, mesmo que se tenha desenhado um quadro de violências e subalternizações, deve-se ressaltar que os estudantes aqui apresentados não são vítimas passivas desses processos. Ao contrário, estabeleceram agências sobre suas vidas e definiram formas de resistência das maneiras mais diversas possíveis. Isso envolveu, como apresentado em alguns relatos, tanto a luta física quanto o questionamento das ideias que os inferiorizavam - o que se relaciona diretamente com a forma como modularam suas experiências nos lugares de educação formal. Seria necessário um novo texto para tratar de suas agências, ainda sim, estas/es estudantes nos deixam um exemplo vivo de que o racismo não é absoluto e, como um processo social que produz espacialidades de subalternização, pode ser desconstruído, revertido e refeito para espacialidades mais humanas.

\section{REFERÊNCIAS}

BERNARDO, T. Memória em branco e preto: olhares sobre São Paulo. São Paulo: EDUC, UNESP, 1998.

BOURDIEU, P. A ilusão biográfica. In: AMADO, J.; FERREIRA, M. M. (orgs.). Usos e abusos da história oral. Rio de Janeiro: Ed. FGV. 1996. p.183-191.

BRASIL. Educação e Anti-racismo: Caminhos Abertos Pela Lei Federal No 10.639/03. Brasilia: Secad/Mec, 2005.

CARNEIRO, A. S. A construção do outro como não-ser como fundamento do ser. Tese de Doutorado em Educação. São Paulo: USP, 2005.

CASTRO, M. G.; RIBEIRO, I. R. Juventude, raça/etnia Diferenciais e desempenho escolar. In: PINHO, O.; SANSONE, L. (org.). Raça Novas Perspectivas Antropológcas. Salvador: Associação Brasileira de Antropologia; Edufba, 2008.

CASTRO, M. G.; ABRAMOVAY, M. (Coords.). Relações raciais na escola: produção de desigualdades em nome da igualdade. Brasilia: Unesco, 2006.

CAVALLEIRO, E. Discriminação Racial e Pluralismo nas Escolas Públicas da Cidade de São Paulo. In: BRASIL. Educação e Anti-racismo: Caminhos Abertos Pela Lei Federal $\mathbf{N}^{\mathbf{1}}$ 10.639/03. Brasilia: Secad/Mec, 2005. p.65104.

Do silêncio do lar ao silêncio escolar: racismo, preconceito e discriminação na na Educação Infantil. São Paulo: Humanitas, 2000.

CIRQUEIRA, D. M. Trajetórias sócio-espacial de estudantes negras e negros da Universidade Federal de 
Goiás. Monografia de Graduação em Geografia. IESA-UFG,2008.

Entre o corpo e a teoria: a questão étnico-racial na obra e na trajetória sócio-espacial de Milton Santos. Dissertação de mestrado em Geografia. Goiânia: IESA- UFG, 2010.

CIRQUEIRA, D. M.; CORRÊEA, G. S. questão étnico-racial na geografia brasileira: um debate introdutório sobre a produção acadêmica nas pós-graduações. In: Revista da Associação Nacional de Pós-graduação e Pesquisa em Geografia (Anpege). V.10, n.13, jan-jun.2014. p.29-58.

CLAUDIA. Entrevista. Entrevistador: Diogo Marçal Cirqueira. Goiânia,out. 2008. 1 arquivo mp3 [67min.].

COLLINS, P. H. Mammies, matriarchs, and other controlling images. In: J. KOURNAY, J.; STERBA, J.; TONG, R. (org.). Feminist philosophies. 2 ed.. Upper Saddle River: Prentice Hall, 1999.p. 142-152.

CRESSWELL, T. Place a short introduction. New York: Blackwell, 2004.

DOCI. Entrevista. Entrevistador: Diogo Marçal Cirqueira. Goiânia, out. 2008. 1 arquivo mp3 [58min].

GOMES, N. L. A mulher negra que vi de perto: o processo de construção da identidade racial de professoras negras. Belo Horizonte: Mazza Edições, 1995.

GOMES, N. L. Alguns termos e conceitos presentes no debate sobre relações raciais no Brasil: uma breve discussão. In: BRASIL. Educação e Anti-racismo: Caminhos Abertos Pela Lei Federal No 10.639/03. Brasilia: Secad/ Mec, 2005. p. 39-63.

GONÇALVES, C. P. Cotas e antirracismo na universidade pública brasileira. Goiânia: Ed. UFG, 2014.

GONZALEZ, L. A juventude negra brasileira e a questão do desemprego. Texto apresentado na Segunda Conferência Anual do African Heritage Studies Association Abril, 1979. p. 26-29.

HÄGERSTRAND, T. What about people in regional science? In: Papers of the Regional Science Association. n. 24, p. 7-21.
HENRIQUES, R. Raça e gênero nos sistemas de ensino. Os limites das políticas universalistas de educação. Brasilia: UNESCO, 2002.

HENRIQUES, R. Desigualdade racial no Brasil: Evolução das condições de vida na década de 90 . Rio de Janeiro: IPEA, 2001.

\section{INSTITUTO DE PESQUISA ECONÔMICA APLICA-}

DA. Desigualdades raciais,racismo e políticas públicas: 120 anos após a abolição. Brasília: IPEA, Diretoria de Estudos Sociais, 2008.

JAIME, P. Preto rico nem sempre é branco: trajetórias profissionais de executivos negros. Anais do VII RAM - UFRGS, Porto Alegre, Brasil - GT 03 Raza, cultura y nación em el Mercosur, 2007.

KARJALAINEN, P. T. On Geobiography. In: PAIK, K. Place and Location. Tallin, 2003. p. 87-92.

KIZZY. Entrevista. Entrevistador: Diogo Marçal Cirqueira. Goiânia, set. 2008. 1 arquivo mp3 [53min].

KOFES, S. Uma trajetória, em narrativas. Campinas: Mercado de Letras, 2001.

LEJEUNE, P. On autobiographical pact. In LEJEUNE, P. In: On Biography. Journal of Modern Literature, Volume 17, Issue 2-3, 1990, , 1p. 03-33.

MASSEY, D. Pelo espaço: uma nova política da espacialidade. Rio de Janeiro: Bertrand Brasil. 2008.

O sentido global do lugar. In: ARANTES, A. A. (org.). $\mathbf{O}$ espaço da diferença. Campinas: Papirus, 2000. p. 176-186.

Space, place and gender. Minneapolis: University Avenue Southeast, 1994.

MAYA. Entrevista. Entrevistador: Diogo Marçal Cirqueira. Goiânia, set. 2008. 1 arquivo mp3 [67min.].

MCKITTRICK, K. Demonic Grounds: Black Women and the Cartographies of Struggle. Minneapolis: University of Minnesota Press, 2006.

MILTON. Entrevista. Entrevistador: Diogo Marçal Cirqueira. Goiânia, set. 2008. 1 arquivo mp3 [52min]. 
MOORE, C. Racismo e sociedade. Belo Horizonte: Mazza, 2007.

MOSS, P. (org). Placing Autobiography in Geography. Syracuse, New York: Syracuse University, 2001.

MUNANGA, K. Superando o racismo na Escola. Brasilia: SECAD/MEC, 2005.

Rediscutindo a mestiçagem no Brasil: identidade nacional versus identidade negra. Belo Horizonte/MG: Autêntica, 2004.

NOGUEIRA, O. Tanto preto quanto branco: estudos de ralações raciais. São Paulo: Queiroz Editora, 1985.

OLIVEIRA, I.B.; ALVES, N. (Org.). Pesquisa no/do cotidiano das escolas: sobre redes de saberes. Rio de Janeiro: DP\&A, 2001.

PAIXÃO, M.; ROSSETTO, I.; MONTOVANELE, F; CARVANO, L. M. (Orgs.). Relatório anual das desigualdades raciais no Brasil: 2009-2010. Rio de Janeiro: Garamond, 2010.

PEREIRA, E. A.; GOMES, N. Pe. Ardis da imagem: exclusão étnica e violência nos discursos da cultura brasileira. Belo Horizonte: Mazza/ Editora PUC-MG, 2001.

QUEIROZ, D. M. Universidade e desigualdade: brancos e negros no ensino superior. Brasilia: Liber Livro, 2004.

RATTTS, A. J. P.; DAMASCENA, A. A. Experiências de ação afirmativa: interlocução com o ponto de vista da juventude negra. In: BERNARDINO, J.; GALDINO, D. (orgs.). Levando a raça a sério. Rio de Janeiro: DP\&A, 2004. p. 173-188.

RATTS, A. As etnias e os outros: as espacialidade dos encontros/confrontos. Espaço e cultura, UERJ, Rio de Janeiro, No 17-18, Jan/Dez de 2004. p.77-89.

Gênero, raça e espaço: trajetórias de mulheres negras. Comunicação apresentada no $27^{\circ}$. ENCONTRO ANUAL DA ANPOCS (Associação Nacional de Pós-Graduação e Pesquisa em Ciências Sociais), Caxambu, MG, 2003, 18p. (mimeo)

Os lugares da gente negra: temas geográficos no pensamento de Beatriz Nascimento e Lélia Gonzalez. In: SANTOS, R. E. Questões urbanas e racismo. Petrópolis, Brasilia: DP, ABPN, 2012. p. 216-243.

REGARD, F. Autobiography and Geography: A Self-Arranging Question. In: Autobiogeography: considering space and identity. Reconstruction, Summer 2002: Volume 2, Number 3. P.

RELATÓRIO DE DESENVOLVIMENTO HUMANO. Racismo, pobreza e violência. Brasília: PNUD,2005.

RELPH, E. As bases fenomenológicas da geografia. Geografia, Rio Claro, v. 4,1978, p. 1-25.

Place and Placelessness. London: Pion, 1976.

RESENDE, M. S. A geografia do aluno trabalhador caminhos para uma prática de ensino. São Paulo, Loyola, 1986.

SANTOS, M. O intelectual negro no Brasil. Ethnos, 1 (1): 7-10, 2002.

Ser negro no Brasil hoje. In: RIBEIRO, W. C. (org.). O país distorcido: o Brasil, a globalização e a cidadania. São Paulo: Publifolha, 2002 [2000]. p. 157-161.

. As exclusões da globalização: pobres e negros. In: FERREIRA, A. M. T. Na própria pele. Porto Alegre: CORAG/Secretaria de Estado da Cultura, 2000. p. 9-20.

SANTOS, R. E. (org.). Diversidade, espaço e relações étnico-raciais: $O$ negro na geografia do Brasil. Belo Horizonte: Autêntica, 2007.

(org.). Questões urbanas e racismo. Brasília, Petrópolis: DP e A, ABPN, 2012.

. Ensino de Geografia e currículo: questões a partir da lei 10.639. Terra Livre: Crise, práxis e autonomia: espaços de resistência e de esperanças. São Paulo/SP. Ano 26, v. 1, n. 34, jan-jun/2010. p. 141-160.

Movimentos Sociais e Geografia: sobre as espacialidades da ação social. Rio de Janeiro: Consequência, 2011.

PEDRO PAULO. Entrevista. Entrevistador: Diogo Marçal Cirqueira. Goiânia, set. 2008. 1 arquivo mp3 [47min]. 
SOFIA. Entrevista. Entrevistador: Diogo Marçal Cirqueira. Goiânia, set. 2008. 1 arquivo mp3 [62min].

SOUZA, L. F. Corpos negros femininos em movimento: trajetória socioespaciais de professoras negras em escolas públicas. Dissertação de Mestrado em Geografia. IESA - UFG, 2007.

SOUZA, M. L. Os conceitos fundamentais da pesquisa sócio-espacial. Rio de Janeiro: Bertrand Brasil, 2013.

SOUZA, N. S. Tornar-se negro. São Paulo: Graal, 1983.

TEIXEIRA, M. P. Negros na universidade: identidade e trajetória de ascensão social no Rio de Janeiro. Rio de Janeiro: Pallas, 2003.

TELLES, E. E. Race in Another America: The Significance of Skin Color in Brazil. Princeton, NJ: Princeton UP, 2004.

Race, Class and Space in Brazilian Cities. International Journal of Urban and Regional Research 19(3): 395-406, 1994.

TUAN, Y. Espaço e Lugar. São Paulo: Difel, 1983.

Geografia Humanística. In: CRISTOFOLETTI,

A. (org.) Perspectivas da Geografia. São Paulo: Difel, 1985 [1976], p. 143-163.

Who Am I? An autobiography of emotion, mind and spirit. Wisconsin: The University of Winsconsin Press, 1999.

VARGAS, J. C. Apartheid Brasileiro: Raça e Segregação Residencial no Rio de Janeiro. Revista de Antropologia, USP, v.48 (1), 2005.

WOLF-MEYER, M.; HECKMAN, D. Navigating the Starless Night: Strategies for Understanding Autobiogeography. In: Autobiogeography: considering space and identity. Reconstruction, Summer 2002: Volume 2, Number 3 .

ZORA. Entrevista. Entrevistador: Diogo Marçal Cirqueira. Goiânia, out. 2008. 1 arquivo mp3 [49min].

\section{Notas de Fim:}

1- Agradeço as relevantes críticas e sugestões dos pareceristas anônimos para a elaboração desse artigo. Do mesmo, sou grato a Priscilla Teodósio Rosa pela criteriosa revisão.

2- Seguindo as indicações de Souza (2013) aqui será grafado o termo "sócio-espacial" com hífen, uma vez que, diferente de "socioespacial" sem hífen, busca-se expressar que há uma interação e retroalimentação entre estruturas espaciais e relações sociais, ainda que cada uma componha uma individualidade epistemológica.

3- As entrevistas que compõem essa pesquisa foram realizadas junto a estudantes da UFG. À época da pesquisa (2008), nos Campus da UFG em Goiânia havia cinquenta e sete cursos de graduação. Assim, buscou-se selecionar os sujeitos da pesquisa de forma a agregar um conjunto heterogêneo de vivências, experiências e perspectivas acerca dos lugares da educação formal dos estudantes na instituição. Foram entrevistadas(os), portanto, treze estudantes negras(os), sendo: dez mulheres e três homens. Os cursos que frequentavam eram: Biblioteconomia, Artes Visuais, Ciências Sociais, Educação Musical, Filosofia, Pedagogia, Geografia, Economia, Nutrição, Medicina e Jornalismo. A idade mínima entre as (os) estudantes era de dezenove e a máxima de trinta e quatro anos. No entanto, a maioria das(os) entrevistadas (os), tinha uma média entre vinte dois e vinte três anos. Referente ao turno em que frequentavam as aulas na UFG, sete estudavam durante no período matutino, uma no período vespertino, três no período integral e, as outas três no período noturno. Nesse conjunto, sete estavam em seu segundo ano de faculdade, já cursada; três no quarto ano de faculdade e três em seu quinto ano.

4- Deve-se ressaltar que, como enfatizam Sínteses de Indicadores Sociais divulgados pelo IBGE, apesar de ter triplicado (de 10\% em 2001 para 35,8\% em 2011) a presença de pessoas negras no ensino superior, esses se concentram em universidades particulares de menos prestígio. Além do que, além de de pessoas brancas passarem de $35 \%$ em 2001 para $65 \%$ em 2011, ocupam aproximadamente $80 \%$ das vagas em instituições universitárias públicas.

5- Compreendendo a categoria lugar como "centro de significado" (TUAN, 1982, p. 149), a geografia humanística é importante aqui porque vislumbra a "natureza da experiência, a qualidade da ligação emocional aos objetos físicos, as funções dos conceitos e símbolos na criação da identidade do lugar." (Idem, p. 149-150). Assim, na visão de Tuan (1982, p. 160), "um dos papéis do geógrafo humanista é o de um agente intelectual; [pois] toma essas pepitas de experiência como capturadas na arte e decompõe-nas em temas mais simples que podem ser sistematicamente ordenados. Uma vez que a experiência seja simplificada e dada uma estrutura explícita, seus componentes podem produzir uma explanação científica".

6- Baseado em Massey (2008), deve-se ressaltar que - diferente do que se costuma pensar - o lugar nem sempre envolve experiências desejáveis, boas lembranças, homogeneidade, segurança, estabilidade, ordem, relações de apoio ou inclusão. Em alguns casos, o lugar pode ser o centro de experiências pesarosas, marcadas pelo medo, desordem, instabilidade, exclusão, heterogeneidade, enfim, fonte intensa de experiências topofóbicas.

7- A fim de conservar a integridade pessoal dos sujeitos da pesquisa, foram utilizados nomes fictícios.

8- Cavalleiro (2000) aponta a existência do "silêncio escolar" acerca 
do racismo para o qual vários agentes do sistema educacional colaboram, incluindo gestores/as e professores/as. Este silêncio, apesar de não expresso em falas não é ausente de discurso, pois, o mesmo se materializa na constituição das frustrações e traumas de crianças e adolescentes negros/as, uma vez que o silêncio sobre as práticas racistas na escola favorecem para com naturalização das desigualdades.

9- A estudante se remete a uma vaga de emprego que concorreu.

10- Sobre esse projeto ver Ratts e Damasceno(2004).

\section{Correspondência do autor:}

Diogo Marçal Cirqueira

e-mail: diogomc@id.uff.br

Artigo recebido em: 25/09/2016

Revisado pelo autor em: 11/01/2017

Aceito para publicação em: 14/03/2017

Geografia, Ensino \& Pesquisa, Vol. 21 (2017), n.2, p. 72-87

ISSN: 2236-4994 DOI: 10.5902/2236499424136 